\title{
Project Planning and Implementation in Niegria: Revisiting International Best Practices
}

\author{
Nick Ngozi Igwe \\ PhD, FIPMD, MAMN, MNIM, MIMC, MTRCN,
}

Assoc. Professor and Head of Department Business Management

Godfrey Okoye University, Ugwuomu-Nike, Enugu, Enugu State Nigeria

\section{Anthony Obiora Ude}

$\mathrm{PhD}$, AMNIM, MCPN

Department of Management

University of Nigeria, Enugu Campus, Enugu State, Nigeria

Doi: 10.19044/esj.2018.v14n14p152 URL:http://dx.doi.org/10.19044/esj.2018.v14n14p152

\begin{abstract}
The existence of poor project planning and implementation culture is an anti-thesis to development. This is because the growth of any nation is essentially dependent on successful execution of critical development projectsand infrastructures. The purpose of thispaper is to explore the current issues around project planning and implementation in Nigeria's public sector vis-à-vis international best practices. The methodology adopted was a documentary review of past and current literature which enhance critical and contextual analysis of project implementation and execution culture in the country. It was found that the three tiers of government have not really planned, implemented and executed projects with due diligence in accordance with global best practices. Thus there exists a widespread institutional mediocrity in project execution, deficiency of vision, and inadequate budgetary allocations leading to high cost of project financing and corruption in the long run. The paper recommends amongst other things the establishment of National Public Projects Implementation System (NPPIS),public projects governance institutional framework and project management offices (PMOs), in Ministries Departments and Agencies to support processes for better public projects delivery system.
\end{abstract}

Keywords: Project, Project Planning, Project Implementation, Best Practice, Public Project Management Office 


\section{Introduction}

The existence of poor planning implementation and execution culture is an antithesis to development. All of mankind's greatest accomplishments from building the great pyramids to discovering a cure for polio, ebola and even putting a man on the moon began as a project. It is nearly impossible to pick up a Newspaper, government periodicals or business magazine and not find something about projects. Project Planning and Implementation is no longer a special-need management. It is rapidly becoming a standard way of doing both private and public sector businesses (Gray and Larson, 2008). This is because the growth of any developed or developing nation is hinged upon successful project planning and implementation of development projects and infrastructures. For the projects to be successfully executed and completed, they must be adequately planned, budgeted for and funded. Funding is normally done by government or donor agencies through the allocation of scarce resources. This brings us to the general view held by economists that every resource has an alternative use, hence an opportunity cost. The implication is that any project embarked upon not only consumes resources but denies other potential projects the opportunity to exist and contribute to the growth of the country especially in this time of economic recession biting every individual, group, organisation and even government. That is why the failure of a project be it in private or public sector through poor projects planning and implementation practices carries three serious repercussions to the economy and environment. First is the waste of resources/finances and human effort(s) used in its execution. Secondly is the denial of opportunity for other projects from coming on streams. Thirdly is the consequence on the mental psyche of the failure syndrome on the project participants and stakeholders (Ewurum, Eboh and Igwe, 2009). As Okorafor (1997) remarks, that it is better not to embark on a project implementation than to start, get stuck and abandon.

A critical look at our environment today especially in the South East would reveal the ugly sights of poorly planned, uncompleted, abandoned and/or even aborted projects. Observable examples of these projects are in the areas of road construction, airports, electricity, water and hospital projects. If their costs were to be calculated, it would reveal a colossal waste of scarce resources (Ikedianya, 1998; Eboh and Igwe, 2007). The question on the lips of every cost sensitive patriotic professional has been: were there no proper feasibility studies before executing these projects? It seems very strange and unfortunate that political expediency overrides every other consideration in the selection of projects for execution in Nigeria. Inother words, such projects are never implemented with the needs and aspirations of the would-be beneficiaries. Commenting on this lackadaisical attitude to project planning and implementation, Imaga, Igwe and Nwoji (2005), aptly stated that the 
problem is that of poor conceptualization and management of development projects, most of which have inbuilt deceitful mechanism meant to serve and sub-serve selfish and self-centred objectives other than national interests and that of improving the lots of Nigerian people. In other climes theseactions would have sent the perpetrators of such crimes against the masses to outright life imprisonment. Given the poor track record of project planning and implementation in Nigerian environment, the significance of sound project management practices cannot be over emphasized. Sound project management has gained popularity as a distinct management concept used to drive change objectives in business organisations and also the economic agenda of developing countries including Nigeria. Consequently, any research that attempts to analyze project planning and implementation in the context of international best practices would be meaningful to re-inventing administrativeand transformational strategies, for sustainable project development and implementation. This paper is intended to fill this gap.

The paper therefore seeks to explore the issues around project planning and implementation in Nigerian public sector in relation to international best practices in other climes especially the developed economies. The paper highlights the urgent need for value-driven project monitoring and evaluation especially the United Nations Development Programmes (UNDP) and the World Bank Models. The paper is divided into sections. The introductory section is followed by conceptual definitions which briefly discuss the concepts around the topic. Sections three and four present the methodology adopted and the literature review on project planning and implementation respectively.The section five throws light on the dynamics of project implementation and completion in Nigeria. Section six presents the proven international best practice success factors in project planning and execution. Section seven and eight respectively present the conclusion and the recommendations towards a value-driven project planning and implementation culture in Nigeria.

\section{Conceptual Framework}

Imaga, Igwe and Nwoji (2005) define project as a scientifically evolved work plan devised to achieve a specific objective within a specified period of time. For Gray and Larson (2008), a project is a complex, nonroutine, one-time effort limited by time, budget, resources and performance specifications designed to meet customer needs. While project has several definitions, a simple and relatively inclusive one is that a project is a sequence of tasks performed to achieve a unique goal within a specific time frame (Mingus, 2002). Uniqueness is the key word. It is what separates projects from operations and what makes them more difficult to manage. To standardize further on the definition of the word, the Project Management Institute (2008) 
in its Project Management Body of Knowledge (PMBOK) Guide defines a project as a temporary endeavour undertaken to create a unique value or service. Meredith and Mantel Jr.(2000) view projects as characterized by general attributes such as the purpose, life cycle, uniqueness, interdependencies and conflicts. Project management is the planning, directing and controlling of organization's resources for a relatively short term objective that has been established to complete specific goals and objectives (Kerzner, 2002). For this paper project is viewed as a related set of tasks planned, performed and coordinated to achieve a specific objective or output at a given location within a limited scarce resource and period of time. For the Project Management Institute (2006) project management is "the application of knowledge, skills, tools and techniques to project activities, in order to meet or exceed stakeholders' needs and expectations. It is designed to make better use of existing resources by getting work to flow horizontally as well as vertically within the project organization. The growth of application of sound project management principles has come about through necessity than through desire. The economic environment in Nigeria and indeed other developing countries today characterized byfrequent changes in monetary and fiscal policies have made it more imperative for sound management of projects in business and public sectors.

Project planning is concerned with establishing a predetermined course of action within a forecasted environment. Planning involves decision making of choosing alternative courses of actions to accomplish the project set objectives. Banjoko (2009) remarks that project planning involves all managerial activities necessary in structuring a course of action. Consequently, project planning in the project environment must be systematic, flexible enough to handle unique activities, disciplined through reviews, controls and ever ready to accept multifunctional inputs. Planning is never "etched on concrete". Project implementation in the public sector management represents a well-considered and thought-out plan of action required to deploy resources considered appropriate and adequate to achieve the desired objectives and quality specifications in an environment. A project is implemented through programs, activities and tasks that serve to deploy resources to interact within the environment.International best practice for this paper would be seen as specifications, standards or benchmarks that have been agreed, promoted by academics, practitionersdonors and stakeholders for achieving objectives in a stable and dependable environment.

Project Planning and Implementation cannot succeed unless a good project manager is in control. A project manager is the individual responsible for the success of a project in terms of time, cost and technical performance (Ewurum, Eboh and Igwe, 2009). He provides the management and leadership necessary to bind the people and groups from different departments and 
companies working on a project into one managerial organization and team. The project manager throughout the life cycle of the project is able to see the project as a whole and also see how the various parts fit together. He is like an "ombudsman" between the customer and the top-management. The project manager is a senior manager and therefore performs all the functions of a manager particularly as regards the success of the project.

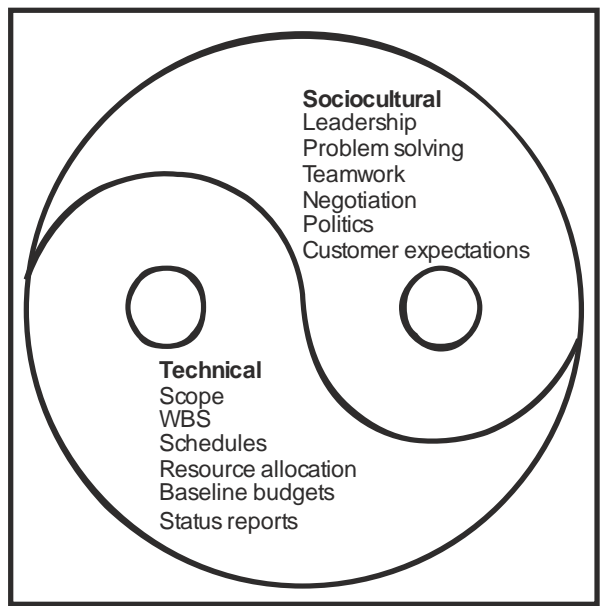

Fig. 1.0: The Technical and Sociocultural Dimensions of the Project Management Process.

Source: Gray C. F. and Larson, E.W (2008: 15) New York: McGraw Hill.

As the diagram, figure 1.0 indicates the technical dimension represents the "science" of project management while the sociocultural dimension represents the "art" of managing a project. To succeed, the project manager must master the two aspects. Unfortunately, some project managers becomepreoccupied with the planning and technical details of the project while some rely heavily on team dynamics and organizational politics. Sound and intelligent project managers balance their attention to both the technical and sociocultural dimensions of project management.

The two traditional measurements for project success are that the project be on time and within budget. There are, however three additional measures of success that need to be considered:

- Were the project goals met (scope)

- Was the client satisfied? (Quality)

- Were there casualties, either to the team or to the interrelationships?

Unfortunately, many people concentrate so much on the first two: time and budget. They fail in the later three. While this may be good for the project managers and their organizations in the short term, in the long term it has a detrimental effect (Mingus, 2002). The interrelationships of these five measures of project success can be represented graphically in what is often 
referred to as the project management Triangle or Time Cost Scope. Triangle (Fig. 2.0).

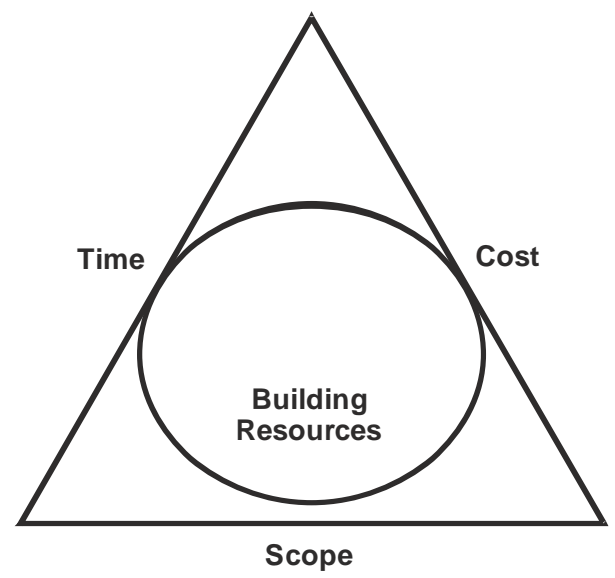

Fig. 2.0: Project Management Triangle

Source: Mingus, N. B. (2002:9): Teach Yourself Project Management in 24 hours, Madison: CWL Publishing.

The agreed upon project work and requirements, the cost side represents the total naira cost of the project and the time side represents the project duration. Inside the triangle, resources refer to the people and equipment in use on the projects and Quality to how close the project is to satisfying client expectations. What the diagram portrays is that there is a relationship between the scope of a project, how long that project will take and how much it will cost.

\section{Methodology of the study}

The paper adopts the methodology of documentary review of past and current literature which enhance critical and contextual analysis of project planning and implementation in the Nigeria environment. The issue of large scale, pervasive institutional mediocrity, poor conceptualization, wrong design and faulty execution of projects by many self-seeking public officials and dubious contractors is of serious concern to well-meaning people, researchers, project management professionals and even government. This has attracted a plethora of public outrage and documentary.

\section{Review of Related Literature}

The Critical Factors Necessary for Successful Project Implementation and Execution

Despite the challenges and failures, projects will remain the dominant means of organizing investment in the foreseeable future especially in the developing countries. They offer important advantages to all participants in development, government agencies, non-governmental organizations, 
international donors, aid agencies and beneficiaries. This is because, by definition, they are or should be manageable units of activity. A properly designed project should be a related set of tasks co-ordinated to achieve a specific objective or output at a given location within a limited budget and period of time.

The process of project implementation involves the successful development and introduction of projects in the organization currently, presents an on-going challenge for managers. The project implementation process is complex, usually requiring simultaneous attention to a wide variety of human, budgetary and technical variables. As a result, the organization's project manager is faced with a difficult job, characterized by role overload, frenetic activity, fragmentation and superficiality (Pinto and Levin 1987). Often the typical project manager has responsibility for successful project outcome without sufficient budget or people to handle all of the elements essential for project success. In addition, projects are often initiated in the context of a turbulent, unpredictable and dynamic environment. Consequently, the project manager would be well served by more information about those specific factors critical to project success. These critical factors are discussed as follows:

\section{Need for Planning and Mission Statement}

Planning can be defined as the process of stating project objectives and then determining the most effective activities or accomplishments necessary to reach the objectives. Thus the planning process defines the activities, the time, cost targets and the performance milestones which aid in the successful achievement of the project objectives. The plan must indicate what materials, equipment, facilities, human resources and other resources that are necessary.

In directing the intent of the project, the plan clearly identifies the project objectives, goals and any special influences or constraints on the project scope. Objectives are the end result of a project, whereas the goals are those desired operations, specifications or cost time relationship. What makes the project intents possible is the issue of project mission statement. The mission statements can be identified with the following questions:

- What do we do?

- $\quad$ For whom do we do it?

- How do we go about it? 


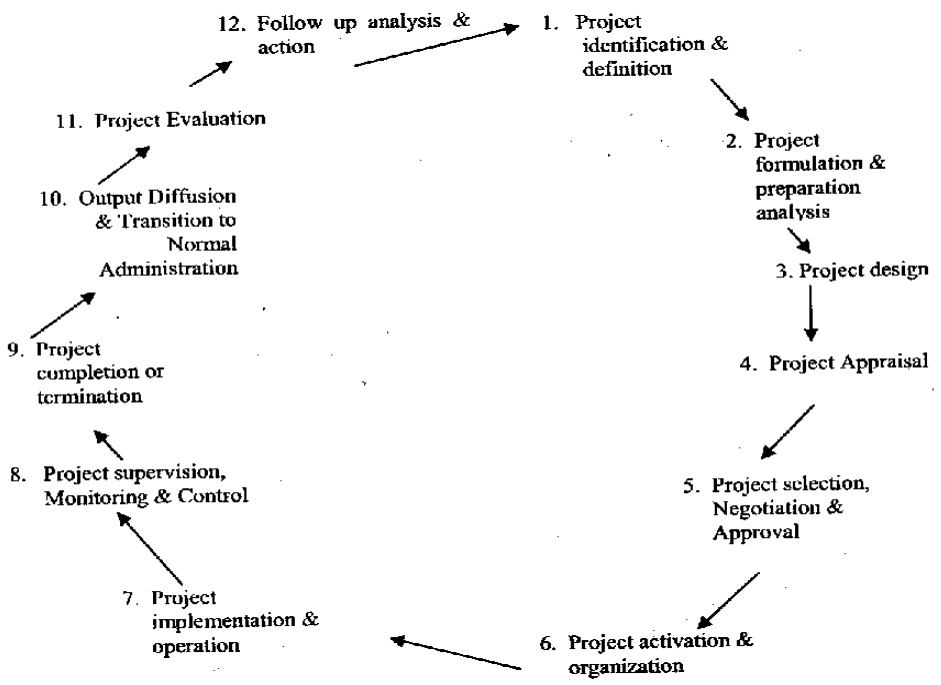

Fig 3.0: Expanded project Life Cycle

Source:Rondinelli, D.A. (1977) Planning Development Project Storudsburg: Hutchison and Ross Inc.

Recognizing that change is inevitable the plan must not be "etched on concrete", it must be sufficiently flexible to permit changes at any point in time during life cycle. But in reality, project management involves a series of related activities, which should form an integrated planning and implementation cycle. Experience suggests that nearly all types of project go through similar life cycles, perhaps not explicit in all cases or in the same way or sequentially as a cyclical framework may imply, but most projects evolve through stages depicted in figure 3 .

\section{Project Manager}

A project manager is the manager responsible for the success of a project in terms of cost and technical performance. He provides the managerial leadership necessary to bind people and group from different departments and companies working on a project into one managerial organisation and teams. He also provides the necessary drive to ensure that the project is completed on time and within the budget. He is a leader and a motivator of the members of the project team.

The functions of the project manager include, amongst others, the following:

- $\quad$ Participates with all responsible managers in developing the overall project objectives, strategies, budgets and schedules. 
- $\quad$ Ensures the preparation of plans for all necessary project tasks to satisfy stakeholders.

- $\quad$ Ensures the rapid and efficient start-up of the project.

- Ensures that all project activities are properly and realistically scheduled, budgeted, provided for, monitored and reported.

- Initiates action to remedy deficiencies and deviations noticed during execution and to monitor the execution of such actions.

- $\quad$ Ensures that payments are received for executed projects in accordance with the contractual terms.

- $\quad$ Arbitrates and resolves any differences between functional units on projecttasks.

- $\quad$ Closely monitors close out activities including the disposal of surplus materials.

For the project manager to perform the above functions effectively and efficiently, he requires the total support of the top management, functional line managers and adequate supply of resources; he needs greatly, clearly, and well defined authority over all who work for him. Authority as we know is the right to give orders and exact obedience.

\section{The Project Team}

The project team includes all functional contributors to the project, as well as the members of the project office. There are however certain actions that the project manager and team can take in order to stimulate project success.

These actions are summarized as follows:

- $\quad$ He should insist on the right to select key project team members with proven track records in their fields.

- Develop commitment and a sense of mission from the client and team.

- He should strive at having key team members in decision making and solving problems; and utilize a, workable set of project planning and control tools.

- $\quad$ Finally he ought to stress the importance of meeting cost, schedule and performance goals.

\section{Support of Top Management}

For a project to succeed, it must have the support of the management. Top level management must be willing to commit organizational resources and provide the necessary administrative support so that the project adapts to the company's day-to-day routine of doing business. As noted by Schultz and Slevin (1985), management support for projects or indeed for any implementation has been considered of great importance in distinguishing 
between their ultimate success or failure. Beck (1983) sees project management as not only depending on top management for authority, direction and support, but ultimately as the conduit for implementing top management's plans or goals for the organization. Furthermore Manley (1985) shows that the degree of management support for a project would lead to significant degree of ultimate acceptance of or resistance to that project (product).

To further extend the boundaries of success, both the top management and project manager must try to take the following joint actions: Select at an early point a project manager with a proven track record of technical skills, human skills and administrative skills (in that order) to lead the project team. Allow the project manager to take key important decisions in conjunction with key team members. They should develop, maintain short and informal lines of communication.

\section{Client Consultation}

The "client" is referred here as anyone who will ultimately be making use of the result of the project, as either a customer outside the company or a department within the organisation. The need for client consultation has been found to be increasingly important in attempting to successfully implement a project. Indeed if the project manager is aware of the major clients he is able to accurately determine if their needs are met.

\section{Personnel Matters}

An important, but often overlooked aspect of the implementation process concerns the nature of the personnel involved. In many situations, personnel for the project team are chosen with less than full regard for the skills necessary to actively contribute to implementation success. Some current writers are including the personnel variable in the equation for project team performance and project success. Hammond (1989) has developed a contingency model of the implementation process which includes people as a situational variable whose knowledge, skills, goals and personalities must be considered in assessing the environment of the project. Only after such a diagnosis takes place that the project management team can begin to set objectives and design the implementation trajectories.

\section{Technical Task Ability}

It is important that the project implementation be managed by people who understand the project. In addition, there must exist adequate technology to support the project. Technical task here refers to the necessity of not only having the necessary personnel for the implementation,but ensuring that they possess the technical skills to perform these tasks. 


\section{Application of Force Field Analysis}

Project management operates in a dynamic environment in which constant and rapid changes become a way of life. To operate effectively under these circumstance, the project manager must be able to diagnose the situation, design alternatives that will remedy it, provide the necessary leadership so that these changes can be implemented and develop an atmosphere that helps people to adapt readily to these changes.

It was Lewin (1951) who propounded that at any point in time during the life cycle of a project, there exists forces that will push the project towards success and restraining forces that induce failure. In a steady state environment, the driving and restraining forces are in balance. However, if the driving forces increase, or the restraining forces decrease whether they act independently or together, change is inevitable to occur. The formal analysis of these forces is commonly referred to as force field analysis.

\section{Client Acceptance}

In addition to client consultation at an earlier stage in the implementation process, it remains of ultimate importance to determine whether the clients for whom the project has been initiated will accept it. Client acceptance refers to the final stage in the implementation process at which time the ultimate efficacy of theproject is to be determined. Too often, ( project managers make the myth of believing that if they handle the other stages of the implementation process well, the client (either internal or external to the organization) will accept the resulting output (product). In fact, as several writers have shown, client acceptance is a stage in project implementation that must be managed like any other variable.

\section{Need for Accurate Monitoring and Feedback System}

This refers to the project control processes by which at each stage of the project implementation, key personnel receive feedback on how the project is comparing to initial projections. Making allowance for adequate monitoring and feedback mechanism gives the project manager the ability to anticipate problems, to oversee corrective measures, and to ensure that no deficiencies are overlooked.

\section{Need for Constant Communication}

The need for constant and adequate communication is extremely important in creating a conducive atmosphere for successful project implementation within the project team itself, but very essential between the team and the rest of the organization as well as with the client.

\section{Troubleshooting}


Problem areas exist in almost every implementation. Regardless of how carefully the project was initially planned, it is impossible to foresee every trouble area or problem that could possibly arise. As a result it is important that the project manager makes adequate initial arrangement for "troubleshooting" mechanisms to be included in the implementation plan. Such mechanisms make it easier not only to react to problems as they arise but to foresee and possibly forestall potential trouble areas in the implementation process.

\section{Need for Risk Analysis}

The simple way to carry out a risk analysis is to think of "what could go wrong?" Usually, a threat is something done by competitors or other people that might impact a project adversely, A risk however, can happen through one's own actions. In practice, risks and threats may overlap. The project manager should know that for every risk identified, it is useful to decide what might be done to deal with the situation. This should help him develop contingencies. Nevertheless, no attempt should be made to identify all of the possible risks that might affect a project. To do so leads to a condition called Analysis Paralysis. However, identification of a risk allows the project manager to take steps to prevent its occurrence by providing a back-up plan.

\section{The dynamics of project implementation and completion in Nigeria}

There seems to be an unambiguous consensus amongst stakeholders, academics and project management practitioners on the relationship between development, successful implementation and completion of projects (Yesufu, 2000; Ewurum, Eboh and Igwe, 2009; Eboh and Igwe, 2007). Nigeria can be considered in all ramifications a leading developing country in Africa despite her numerous political and economic challenges. The country is blessed with abundant deposits of huge hydrocarbons in the Niger Delta region of the country which largely contributes to her wealth and abundant human capital that are contributing immensely in different parts of the world.

However, there is ample evidence to show that inspite of all these enormous resources from Mother Nature, the vast majority of the Nigeria populace are still the poorest in the world. According to the vision 2020 National Technical Working Group Report (2009), the country ranked $177^{\text {th }}$ nation in Human Development Index and $80^{\text {th }}$ out of 108 in the poverty index. In 2015 , the economy of the country went into recession and some of the favourable indices plummeted.

The issue of insurgency in the North eastern region of the country has not helped matters as huge resources have been allocated to reducing the unsavoury effect in the economy. In the North Central and North West geographical zones, farmers and herdsmen attacks result in abandoned 
community farms. In the south east geopolitical zone, the task of curtailing the agitation of indigenous people of Biafra has not been completely degraded. All these various challenges have contributed immensely to under development and a dearth of infrastructural development in various parts of the country.(Babalola, 2014, Felix and Wilson, 2011, Uma, Eboh, Obidike and Ogwuru, 2013). It is in recognition of this that Zuofa and Ochieng (2012) asserted that the execution of roads, dams, rural water supply and other infrastructural projects which support development should be a priority in Nigeria and other developing/emerging economies because such projects instigate developments and contribute towards the alleviation of the effects of most social, political and economic challenges (Zuofa and Ochieng, 2014).

The continued agitations recorded in the recent past against the government of the federation by the various groups of Niger Delta Militants and Indigenous people of Biafra could be traced to poor projects completion culminating in abandonment of such critical developments projects with enhanced capacity for uplifting the standards of living of people in the geopolitical zones. Appalled by the outrages resulting from project failures and abandonment in Nigeria environment, the then President Goodluck Ebele Jonathan instituted the Presidential Project Assessment Committee (PPAC) in March 4, 2010 to among other things take inventory of all on-going projects awarded by the Federal government, assess the level of funding, physically inspect each project to determine work done and to ascertain whether it is commensurate with the amount paid to the contractors.

Presenting the report of the 20 - member committee, the chairman revealed that within the period under review that the Federal Government lost billions of naira to dubious contractors and public officers (Vanguard Newspapers, 2011). Narrating their experiences the committee chairman Engr. Ibrahim Bunu revealed that they physically visited two hundred (200) sites of on-going projects across the country and assessed performance on the sites. He said: "in the process, the committee has made an inventory of 11,886 ongoing capital projects being executed by the Federal Government. The estimated cost implication of these projects stands at N7.78trillion". He added that "out of this outstanding amount, N2.696 trillion had been paid to contractors" leaving a whooping outstanding of over N5 trillion. The committee's in-depth assessment of many of the projects revealed large scale, widespread institutional mediocrity, deficiency of vision and a lack of direction in project management which result in poor conceptualization, poor design and faulty execution, existence of inadequate budgetary allocation, high cost of financing projects and corruption "in the handling of projects by many self-seeking, inept public officers and contractors which led to massive inflation of costs and undermined the legitimacy of their monitoring and supervision responsibilities". 
In his own words: "there are many uncompleted projects where trillions of naira have already been spent and abandoned, prominent example of which is the 30 year old multi-billion dollar Ajaokuta steel complex project. As at 2011, 4.5Bn dollars which had been spent on Ajaokuta steel complex and yet the project remains uncompleted. A breakdown of the project as contained in the report showed that Federal Capital Territory Abuja owed N3.157 trillion worth of projects representing about 34 percent of the total amount of money, South-South zone has 1,755 projects amounting toN2.1trillion followed by North-Central zone with N630Billion with 1,844 projects. The last in ranking was North-East zone with 466 projects amounting to N98billion (Vanguard Newspapers, 2011). The Presidential Project Assessment Committee, PPAC's report was indeed a sad commentary on project implementation, execution and completion culture in Nigeria environment.

The implication of the PPAC's report is that there exists a horde of unimpressive records concerning project outcomes in Nigeria. In the extant body of literature on project failure in Nigeria, Ubani, Nwachukwu and Nwokonkwo (2010) explained that after independence in 1960, many developmental projects have suffered failure and abandonment. Okereke (2012) examined many projects from various sectors in Nigeria and highlighted several shortcoming and achievements. According to him, there was ample evidence to suggest that project failure was not confined to any state but could rather be termed as a national malaise.

In Nigeria, it is very rare to find projects in the public sector that have been completed on time and within budget. The government of Dr. Goodluck Ebele Jonathan outraged by the abysmal project delivery rate of the Niger Delta Development Commission (NDDC) instituted a committee to appraise the activities and performance of the Commission. The presidential monitoring committee on NDDC revealed that of 609 projects monitored, 285 projects representing 46.8 percent were abandoned at various phases of their project life, 222 projects representing about 36.5 percent were completed while another 102 projects representing 16.7 percent were still ongoing as at the time of report (Daily Times, 2013). In a research conducted by Ewa (2013) on root causes of project abandonment in Nigeria tertiary institutions revealed that most of the projects failed to realize the objectives for implementing them.

Additionally, Eboh and Igwe (2007) catalogued some of the abandoned projects in Enugu Metropolis, South East Nigeria since the democratic dispensation begun in 1999. An overview of Nigeria's landscape since 1970 till date would reveal a catalogue of abandoned projects that could not be completed by Federal, State, Local Governments and their agencies. On the national level were such projects like the Federal Government low cost housing project, Nigeria Machine Tools, Ajaokuta steel rolling mill, Lagos 
metroline project, second Niger Bridge Project and Enugu International Airport expansion project. All of these expositions generate valid concerns about the dynamics of project planning and implementation in the Nigerian environment. This study shows a plethora of valid evidence within the body of available literature that this nation has not planned, implemented and executed projects with due diligence given the level of institutions and legislative frameworks put in place to forestall such lackadaisical propensity towards project management principles and practices.

\section{Revisiting Proven International Best Practices Success Factors}

Managing projects requires unique skills different from those needed to manage ongoing operations. Project management in the present $21^{\text {st }}$ century has been confronted with the challenge of operating in an environment characterized by high level of uncertainty, economic recession, culminating in dwindling resources for project implementation, insurgents, kidnapping, herdsmen attacks, bare-faced armed banditry, cross-cultural teams and global competition for competent human resources etc.just to mention but a few. A survey of contemporary research cites the non-existence of internationally acceptable best practices in project planning and implementation in Nigeria and this poses a serious national problem from a global perspective (Zuofa and Ochieng, 2012). Some of the proven international best practices on successful project planning and implementation are discussed as follows:

\section{Risk Assessment Strategy}

As an integral part of project planning and implementation, effective risk management is a critical success factor for delivering projects in defined cost, time and quality. Project risk management provides benefits when it is implemented according to good practices principles and with organisational commitment to taking the decisions and performing actions in an open and unbiased manner (Benita and Podean, 2011). In simple term, risks are uncertain events which when they occur have negative effect on at least one project goal - time, costs, contents or quality. Contrasting the positive variability desired is called opportunity. Despite the aforementioned explanation, project managers most often include risks as challenges and technical or organisational issues. It is well to note that risks are potential events in future which have not occurred while problems are risks that have occurred. Risks are characterized by probability always less than 100 percent and impact measured changes on project objectives. Risks may be measured in costs (monetary risks) in time (delay risks for time management) or quality (usually affecting contracts through monetary costs of improvement), (Smallman, 1999; Spedding and Rose, 2008). Therefore, uncertainty in project planning and implementation is inevitable since projects are unique and 
temporary undertakings based on assumptions and constraints, delivering project results to multiple stakeholders with different requirements.

\section{Monitoring and Evaluation (M \& E)}

Nigeria like many other developing countries has many numerous projects in an attempt to upgrade her infrastructures and subsequently improve the standard of living of its citizens. Unfortunately these projects fail to be successfully completed due to several reasons. Amongst these are lack of understanding of the need for monitoring and evaluation. It is worrisome that many project sponsors especially governments and project managers do not recognise the need and usefulness of this too for successful completion of projects. Although monitoring and evaluation are viewed as related, they are quite distinct and as a result perform distinct functions. Simply put, monitoring is viewed as a process that provides information and ensures the use of such information by management to assess project outcomesfor both intentional and unintentional impact. It is aimed at determining whether or not the intended objectives have been met (Otieno, 1999). Evaluation on the other hand is seen as the process which determines objectively the relevance, effectiveness, efficiency, sustainability and impact of activities in the light of project/program performance. It focuses on the analysis of the progress made towards the achievement of the stated objectives. In most projects/programmes in developing countries, evaluation is not given emphasis in project implementation especially ex-post evaluation in order to measure the impact of projects/programs on the beneficiaries and draw lessons learnt (Burke, 1999). Monitoring and evaluation when carried out professionally at the right time and place are two of these best practices for ensuring the success of many projects in developed climes. Unfortunately, these two tools for project success are not given adequate priority attention by project developers. Even when in place, it is done haphazardly for the sake of fulfilling the requirements of most foreign funding agencies without the intention of using them as a mechanism for ensuring the success of project planning and implementation in Nigeria.

\section{Professionalization of Project Employees}

This is a glaring case of accidental project managers and project management professionals. The accidental project manager has lived in the folklore of business projects for a generation. Accidental project managers are individuals assigned to projects because they were available not because they had any project management knowledge or skills. Some accidental project managers have been remarkably successful, but many find themselves blamed for problems and projects failures they were from the onset ill-equipped to prevent. Cases of collapsed buildings, collapsed bridges and abandoned 
projects are common in Nigeria. It is important to help accidental project managers become successful not only to encourage them to remain in the profession but also because every project failure is a failure for the project management profession (Bourne, 2005). The accidental project manager has a technical background: engineer, programmer, system analyst, sales manager, human resource manager in a HR system or some expertise in the field in which the project is delivering functionality. By contrast, the career project management professional (PMP) will normally have or seek formal project management education or seek exposure in management and organizational skills for improved project success.

\section{Existence of better institutional frameworks}

Public projects governance territory consists of one area of project management. Governance as per project implies employing institutions, authority structures and collaboration in order to assign resources to coordinate activities in a society or economy following laid down procedures. Public project governance is this part of governance which is applied to public projects and covers the area from the government through institutions down to projects (Klakegg, Williams, Magnussen and Glasspool, 2008). In the United States several regulations starting from guidelines on Cost/Schedule Control System Criteria (C/SCS), (DOD, 1967), through Government Performance and Result Act (GPRA) (White House, 1993) up to Program Management Improvement and Accountability Act (PMIAA) (US Congress, 2015) were enacted as cited by (Gasik, 2016)..

$\mathrm{C} / \mathrm{SCS}$ guidelines require that all major defense acquisition projects must apply earned value management value techniques. GPRA laid the foundation for American Public Projects Management. PMIAA requires establishing an interagency body on program management, appointing a senior executive responsible for program management and establishing models of program management in each Federal Institution.

\section{Effective and efficient public procurement contracts}

The Nigerian Public Procurement Act, 2007 requires for the establishment of a national council on public procurement. It is important to realize that there is no single solution to the problem of transparency and accountability in public procurement contracting. Contracting processes need to be permanently monitored. Thus supervision and control play a key role since good rules are necessary but not always enough to curb corruption. Nevertheless, it is important to have clear and transparent procedures and to have regular audits by external parties (Igwe, 2013). This is where the Civil Society Organisations can play an effective role in public projects management processes. 


\section{Existence of infrastructure for public projects management}

This is key to good project planning and implementation strategy, and delivery. Power and communication facilities must be seen to be adequate and available even in the remotest communities where projects are carried out.

\section{Stakeholders Engagement and Management}

The most important stakeholders of public projects are communities for which theseprojects are performed for. They are involved in each phase of the project life cycle from inception to gaining project benefits (Gasik, 2016). Their representatives are obligatorily included into the project selection process and into other projects (PMI, 2006). Public projects typically have multiple other stakeholders like governments, politicians, regulatory bodies, communities of interest to mention just a few of them. Due to the large number of stakeholders, it is important to produce efficient, easily accessible channels of information transfer between actors implementing projects and other stakeholders. Internet tools are used as communication tools. The portals contain data on major projects, their annual reports and information of status (MPA, UK 2013).

\section{The integrative influence of project managers}

In addition to companies, project managers have significant influence on public project. In some countries, the pertinent requirements are formulated and only people who meet these requirements may manage public projects (Gasik, 2016). Requirements for public projects managers usually focus on three core areas: general project management skills, knowledge of the applicable regulationand knowledge of local realities. Furthermore having a certificate issued by a recognized body like the Project Management Institute PMI, may be the basis for recognition as a qualified project manager (PMO, Maine, 2013) certificates that qualify to conduct public projects are also issued upon completion of training organized in a given country, (PAI Ireland, 2013). A more advanced requirement is the completion of full studies in public projects management (University of Oxford, 2012).

\section{Conclusion}

An effective state is the corner stone of successful economies. Different administrations in Nigeria have made concerted efforts to plan and execute development projects. More often than not these projects are riddled with rough shoddy planning and implementation problems. Management and delivery of projects by the three tiers of government have exhibited a high degree of inefficiency, a general lack of the desired capacities, institutional structures required to plan and implement projects that would improve the living standards of the Nigerian people. There is therefore the urgent need for 
the Federal Government to constitute a transparent National Public Projects Implementation System (NPPIS) just like in other developed climes to check project planning and implementation abuses. It cannot continue to be business as usual.

\section{Recommendations/Suggestions}

1. There is need to establish a transparent national public projects implementation system in the presidency powered by an act of the National Assembly. It will regulate projects and development projects planning and implementation.

2. A careful risk management framework must be based on identification of the key factors and the interpendencies among these factors inherent in each project environment. This can be achieved by ascertaining the product of risk probability and impact of the project.

3. There is need for improved effective and efficient monitoring and evaluation of project/ program. This can be done by timely communication of the results of $\mathrm{M} \& \mathrm{E}$ to the users for decision making purposes. It is said that communication in project management is the "oil" that lubricates the project movement in the attainment of stated project objectives.

4. Public projects typically have multiple stakeholders. There is need for engagement and subsequent management can be facilitated by providing accessible channels of information transfer between actors implementing projects and stakeholders.

5. There is an urgent need to check the incidence of accidental project managers. Public institutions can play a pivotal role in this regard with the enactment of project/program improvement and accountability act by the National Assembly.

6. The Federal government can improve on efficient project delivery modes by massive infrastructural development in the critical sectors of the economy such as power, roads, education,communication and health.

7. There is need to enshrine punitive actions against defaulting contractors, project managers, government officials responsible for project failures or abandonment in the constitution through legislation especially when it is established that such actions were as a result of corrupt and unethical conducts.

\section{References:}

1. Babalola, D. (2014). The underdevelopment of Nigeria's Niger Delta Region: Who is to blame? Journal of Sustainable Development, 7(3) 118 - 128. http://doi.org//05539/jsdv7n3p118.

2. Banjoko, S.A. (2009). Production and Operations Management, Ibadan: Pumark Nigeria Ltd., p.114. 
3. Beck, D.R. (1983). "Implementing Top Management Plans through Project Management” Cleland, D.I. and King, W. R. (eds.), New York: Van Nostrand Reinhold.

4. Benta, D. and Podean, I.M. (2011).On best practices for Risk Management in Complex Projects, Journal of InformaticaEconomica 15(2).

5. Bourne, L. (2005) The Accidental Project Manager: The getting of wisdom. Paper delivered at Juggling Anarchy with fearless ability, Project Management Institute of New Zealand, Annual Conference Auckland $13^{\text {th }}-14^{\text {th }}$ October.

6. Burke, R (1999). Project Management Planning and Control Techniques. Third edition.

7. Daily times (2013). Presidential Committee on NDDC submits report. Retrieved from http://www.dailytimes.coming/article/presidentialcommittee-nddcsubmitsreport.

8. DoD, 1967. DoDI 7000.2. Performance Measurement for Selected Acquisitions, Washington: DoD.

9. Eboh, F.E. and Igwe, N.N. (2007). Analysis of Environmental Influences that impinge on Project Completion In Nigeria, $A B S U$ Journal of Management Sciences Vol. 3(1) March.

10. Eboh, F.E. and Igwe, N.N. (2007).Analysis of Environmental Influences that impinge on project completion in Nigeria. $A B S U$ Journal of Management Sciences, Vol. 3, No. 1 March pp. $11-21$.

11. Eboh, F.E. and Igwe, N.N. (2010). Towards an effective Project Management: The Integrative role of Project Managers, ESUT Journal of Management Sciences Vol. 5(2) ISSN: 0794 - 0947 pp.76 - 78.

12. Ewa, U.E. (2013). Root causes of project abandonment in tertiary institutions in Nigeria. International Business Research, 6(11), 149 159, http://doi.org//0.5539/ibr.v6n11p.149.

13. Ewurum, U.J.F., Eboh, F.E. and Igwe, N.N. (2009). Managing Development Projects for success and sustainability in Nigeria, The Nigerian Journal of Development Studies 7(1), ISSN: 0189 - 2614 pp. 125 - 127.

14. Ewurum, UJF, Eboh, F.E. and Igwe, N.N. (2009). "Empirical Investigation of the Project Management Lapses of Non-governmental Organisations in Enugu State" The Nigerian Journal of Management Research 4, 1, pp. 35-37.

15. Felix, J.M. and Wilson, G. (2011). The underdevelopment of Nigeria: who is to Blame - Failure of leadership or her Political Economic System? Lawti: A Journal of contemporary Research 8(3), 267 - 279. 
16. Gasik, S. (2016). A conceptual model of national public projects implementation systems. In Project Management Development Practice and Perspectives, fifth International Scientific Conference on Project Management in the Baltic Countries in the University of Latvia Riga, April 14 - 15 (pp. 82-93).

17. Gray, C.F. and Larson, E.W. (2008).Project Management, the Managerial Process, New York: McGraw Hill, p.15.

18. Hammond J.S. (1989). "A practitioner oriented Framework for Implementation" Project Management Handbook, Cleland, D.I. and King, W. R. (eds.), New York: Van Nostrand Reinhold.

19. Igwe, N.N. (2013). The Role and Responsibilities of Civil Society Organisations in the transparent public procurement process in a Developing Democracy. GOU Journal of Management and Social Sciences Vol. 1(1), pp.21-22.

20. Imaga, E.U.L., Igwe, N.N. and Nwoji, S. (2005). Groundwork of Project Management and Feasibility Analysis Owerri: Ibeson Press, pp. $1-2$.

21. Kerzner, H. (2002). Project Management: A Systems Approach to Planning, Schedulling Controlling, New Delhi: CBS Publishers and Distributors.

22. Klakege, O.J., Williams, T., Magnussen, O.M., Glasspool, H., 2008.Governance Framework for Public Project Development.Project Management Journal, 39 (S1), pp. S27 - S42.

23. Kolb, D.A. and Frohman, A.L. (1980). "An organisation to Consulting" Sloan Management Review 12(1).

24. Lewin, K. (1951) Frontiers in Group Dynamics and Human Relations, New York: Haper P. and Row.

25. Lucas, H. L. (1989). "The Implementation of an Operation Research Model in the Brokerage Industry".The Implementation of a Management Science, D.R. Schultz and Scevin, D.P. (eds.) New York: North Holland Press.

26. Manley, J.H. (1985). "Implementation of Attitudes: A model and Measurement Methodology" Implementing Operation Research and Management Science Schultz, R.C. and Slevin, D.R. (eds.) New York: North Holland Press.

27. Meredith, J.R. and Mantel, S.J. Jr. (2000).Project Management: A Managerial Approach ( $4^{\text {th }}$ ed.). New York: John Wiley and Sons.

28. Mingus, N.B. (2002). Teach Yourself Project Management in 24 hours, Madison: CWL Publishing, p.7.

29. MPA UK, 2013. Major Projects Authority. [Online] Available at: https://www.gov.uk/ government/policy-teams/126. [Accessed 7, September, 2013]. 
30. Ofori, D.F. (2013). Project Management Practices and Critical Success Factors.A Development country perspective.International Journal of Business and Management 8(21) ISSN 1833-3850.

31. Okereke, O.C. (2012). A long term project management analysis of the recent \$1.1billion Chinese loan to Nigeria.PM World Journal 1(4), 1 7.

32. Otieno, F.A.O. (1999). Business Strategy Assignment Three and Four - Company Analysis of the University of Durban Westville, South Africa.

33. PAI Ireland, 2013.Course Certificate in Public Sector Project Management.[Online]. Available

at: http://www.publicaffairsireland.com/events/743-certificate-in-publicsector-project-management. [Accessed 29 October, 2013].

34. Pinto, J.K. and Sleven, D.P. (1987). "Critical Success Factors in Successful Project Implementation” IEEE Transactions in Engineering Management, 34(1).

35. PMI, 2006.Government Extension to the PMBOK Guide. Third Edition Newton Square: PMI.

36. PMO Maine, 2013. Cross Functional Work Flow Document [Online]. Available at:http://www.maine.gov/oit/project management/Cross Functional Work Flow for all OIT Woek and Project Request Final V1\%200.htm.[Accessed 5 October 2013].

37. Rondinelli, D. A. (1977). "Why Development Projects Fail: Problems of Project Management in Developing Countries". Project Management Quarterly7(1).

38. Schultz, R. L. and Slevin, S. P. (1985).“'Implementation and Management of Innovation" Implementing Operations Research and Management Science. Schultz, R. C. and Slevin, D. P. (eds), New York: Elsevier Publications.

39. Sedding, L. and Rose, A. (2008).Business Risk Management Handbook.Elsevier. ISBN: 978-0-7506-8174-2.

40. Smallman, C. (1999). Knowledge Management as Risk Management: A need for open governance? Journal of Risk Management 1(4) pp. 7 -20 .

41. Steven, A. (1979) "Implementation of Risk Analysis" Implementation of Management Science Doktor, R. Schultz, R. C. and Slevin, D. P. (eds), New York: North Holland Press.

42. Ubani, E.C., Nwachukwu, C.C. and Nwaokonkwo O.C. (2010).Variation factors of project plans and their contributions to project failure in Nigeria, American Journal of Social and Management Sciences $\quad 1(2), \quad 141$ 149.http://dx.doi.org//10525//ajsms.20101.2. 141 - 149. 
43. Uma K.E., Eboh, F.E., Obidike, P.C. and Ogwuru, H.O.R. (2013). Poverty, Underdevelopment and emerging Economies: Nigeria in rows. Global Journal of Management and Business Research Finance, 13(6).

44. University of Oxford, 2012. Oxford teams up with Cabinet Office to teach leadership. [Online]. Available at: http://www.ox.ac.uk/media/news_stories/2012/120107.html. [Accessed 11 October, 2013].

45. US Congress, 2015.H.R. 2144 - Program Management Improvement and Accountability Act of 2015.[Online]. Available at: https://www.congress.gov/bill114th-congress/house-bill/2144/text, [Accessed 6 February, 2016].

46. Vanguard Newspapers (2011). Why most government projects Fail?Panel. Retrieved from http://www.vanguard.com2011/06/why-mostgovernment-projects-fail?

47. Vision 2020 National Technical Working Group Report (2009). Retrieved from http://www.npc. gov.ng/vault/files/human\%20development\%20report.pdf.

48. White House, 1993. Government Performance Results Act. [Online] Available at: http://www.whitehouse.gov/omb/mgmt-gpra/gplaw2m, http://www.whitehouse.gov/omb /perfomance/gprm-act. [Accessed 8 September 2013].

49. Yesufu, T. M. (2000). "The Human factor in National Development in the Nigerian Economy: Growth without Development, University of Benin Social Science series for Africa, Benin: University Press.

50. Zuofa, T. and Ochieng, E.C. (2012). The Advancement of Project Management Practice in Developing countries: The case of Nigeria. PMI Research and Education Conference Limerick Ireland, 15 - 18 July.

51. Zuofa, T. and Ochieng, E.C. (2014). Project failure: The way forward and Panacea for Development, International Journal of Business and Management, doi.105539/ijbmv9n /p/59. 